\title{
FAKTOR-FAKTOR PENGARUH TINGKAT PENDIDIKAN ANAK DI PEMUKIMAN KUMUH KOTA MAKASSAR
}

\author{
St. Hasmiah Mustamin \\ Fakultas Tarbiyah dan Keguruan UIN Alauddin Makassar \\ Kampus II: Jalan Sultan Alauddin Nomor 36 Samata-Gowa \\ Email: miah_nina@yahoo.co.id
}

\begin{abstract}
Abstrak:
Penelitian ini bertujuan untuk mengetahui tingkat pendidikan anak dan faktorfaktor yang berpengaruh terhadap tingkat pendidikan anak pada pemukiman kumuh Kota Makassar. Metode penelitian yang digunakan adalah metode survei. Populasi dalam penelitian ini adalah keluarga yang mempunyai anak berpendidikan SD sampai Perguruan Tinggi di Kelurahan Lette Kecamatan Mariso. Pengambilan sampel dilakukan dengan random sampling. Hasil penelitian menemukan bahwa tingkat pendidikan orang tua, pendapatan keluarga, dan jumlah anak termasuk dalam kategori rendah. Ketiga hal tersebut merupakan faktor yang sangat berpengaruh terhadap tingkat pendidikan anak.
\end{abstract}

\begin{abstract}
:
This study aims at determining the level of education of children and the factors affecting the level of education of children in the slums area of Makassar. The method used is the survey method. The population of the research is families with children's education from elementary to university in Kelurahan Lette, Kecamatan Mariso. The sample was taken by using random sampling technique. The study found that the level of parental education, family income and number of children were included in the low category. The three of them were the factors that affect the level of children education.
\end{abstract}

\section{Kata kunci:}

Tingkat pendidikan anak, Pendidikan orangtua, Pendapatan keluarga, Jumlah anak, Pemukiman kumuh.

PENDIDIKAN merupakan salah satu aspek pembangunan dan sekaligus merupakan syarat mutlak untuk mewujudkan pembangunan nasional. Oleh karena itu, pendidikan memiliki posisi strategis dalam segala segi pembangunan bangsa, khususnya pada upaya pengembangan sumber daya manusia.

Pengembangan sumber daya manusia dilakukan dengan maksud untuk mewujudkan manusia pembangunan yang berbudi luhur, tangguh, cerdas dan terampil, mandiri dan memiliki rasa kesetiakawanan, bekerja keras, produktif, kreatif dan inovatif, berdisiplin, dan berorientasi ke masa depan untuk menciptakan kehidupan yang lebih baik. Peningkatan kualitas sumber daya manusia diselaraskan dengan persyaratan keterampilan, keahlian, dan profesi yang dibutuhkan dalam pengembangan sumber daya manusia dilakukan pada seluruh masyarakat/bangsa sebagai aset pembangunan, khususnya aparat pemerintah guna meningkatkan kualitasnya dalam melaksanakan tugas dan tanggung jawabnya sebagai pelaksana pembangunan. 
Dalam upaya melaksanakan pengembangan sumber daya manusia, masalah peningkatan mutu pendidikan merupakan faktor utama yang harus diperhatikan. Dalam Undang-Undang RI Nomor 20 Tahun 2003, dijelaskan bahwa Pendidikan Nasional bertujuan untuk mengembangkan potensi peserta didik agar menjadi manusia yang beriman dan bertakwa kepada Tuhan Yang Maha Esa, berakhlak mulia, sehat, berilmu, cakap, kreatif, mandiri, dan menjadi warga negara yang demokratis serta bertanggung jawab. ${ }^{1}$

Salah satu tujuan yang ingin dicapai seperti yang tercantum pada Undang-Undang RI Nomor 20 Tahun 2003 tersebut adalah meningkatkan potensi peserta didik yang mandiri, dengan melalui jalur pendidikan yaitu pendidikan formal, nonformal, dan informal. ${ }^{2}$

Perkembangan pendidikan yang semakin meningkat, baik di daerah perkotaan maupun di pedesaan membuka kesempatan bagi anak untuk memperoleh pendidikan dari berbagai jenis dan jenjang pendidikan mulai dari tingkat SD, SLTP, SMU, sampai pada tingkat pendidikan tinggi, baik pada jenis pendidikan umum, kejuruan maupun keagamaan.

Pendidikan yang diperoleh anak sebelum bersekolah adalah pendidikan keluarga yang dianggap sangat penting untuk mendidik anak, karena lingkungan keluargalah yang pertama di mana anak dibesarkan. Keluarga merupakan wahana yang efektif dalam mengembangkan sumber daya manusia sebagai suatu proses meningkatkan kualitas manusia untuk melakukan pilihan-pilihan. Keluarga dapat dipandang sebagai miniatur bagi gambaran obyektif masyarakat, bangsa, dan negara. Keluarga sebagai institusi sosial mempunyai beragam fungsi yang mencakup seluruh aspek penting dalam kehidupan manusia. Aspek-aspek tersebut antara lain aspek ekonomi, pendidikan, sosial, budaya, kesehatan, keagamaan, hukum, dan sebagainya.

Keluarga merupakan lembaga yang paling penting pengaruhnya terhadap sosialisasi anak, atau proses ajar/pendidikan anak. Dalam lingkungan keluarga, pendidikan atau sosialisasi anak berlangsung sejak anak dilahirkan. Sejak zaman dahulu, orang tua mengharapkan anaknya bisa menjadi kebanggaan keluarga karena kualitasnya dan juga orang tua sekarang, ingin anaknya menjadi "orang yang sukses". ${ }^{3}$

Penduduk yang hidup di lingkungan pemukiman kumuh tidak hanya secara ekonomis merupakan tempat tinggal yang berada di bawah standar (kelayakan), tetapi juga dari aspek sosial, moral, dan keamanan. Lebih memungkinkan terjadinya halhal yang berada di bawah batas kemanusiawian, misalnya kerawanan sosial dalam bentuk kriminalitas, tindak asusila/amoral, dan sebagainya. Di samping itu, satu aspek yang tak dapat dikesampingkan adalah aspek pendidikan sebagai dorongan keras dalam keluarga mempunyai pengaruh yang nyata dalam tingkah laku, keterampilan, dan pengetahuan. Apabila seorang anak telah memperoleh kesempatan pendidikan, maka dalam dirinya telah terjadi proses perubahan dan pembudayaan yang akan meningkatkan harkat dan martabatnya sebagai manusia. Perubahan ini akan meningkatkan kualitas sumber daya manusia dan sekaligus akan menambah kemampuan memperbaiki mutu hidup dan kesejahteraannya. Di lain pihak, pendidikan ti- 
dak hanya untuk mengembangkan pribadi, akan tetapi bersifat lebih luas yaitu untuk pengembangan masyarakat dan bangsa.

Hal ini sejalan dengan pendapat Sutopo bahwa suatu masyarakat atau bangsa hanya dapat berkembang dan maju apabila warga masyarakatnya telah memiliki tingkat pendidikan yang tinggi untuk melakukan pembangunan dan memberikan hasil yang nyata dalam pembangunan. Kenyataan di negara maju membuktikan bahwa negara-negara yang ekonominya kuat dan laju pertumbuhannya mantap adalah juga negara yang tingkat pendidikannya lebih tinggi bagi rata-rata penduduknya. ${ }^{4}$

Kelurahan Lette sebagai lokasi penelitian merupakan salah satu dari sembilan kelurahan yang ada dalam wilayah Kecamatan Mariso. Kelurahan Lette terdiri atas dua lingkungan yaitu Lingkungan Lette dan Lingkungan Kokobungung Lompoa.

Lingkungan Lette merupakan salah satu daerah kumuh yang ada di Kota Makassar. Menurut Makkulau, ada sekitar 37 persen areal wilayah di seluruh wilayah Kota Makassar yang tergolong lingkungan pemukiman kumuh. ${ }^{5}$ Pertumbuhan dan perkembangan pemukiman di Lingkungan Lette Kecamatan Mariso merupakan pemukiman yang sangat padat dan kumuh yang luas wilayahnya 7 ha dengan jumlah penduduk sebanyak 6.449 jiwa. Artinya, tiap hektar dihuni oleh sekitar 921 jiwa. Rumah-rumah penduduk saling berdempetan dan penataannya kurang teratur. Prasarana dan sarana lingkungan seperti jalan memperlihatkan ciri yang belum teratur dengan baik, serta jalan atau lorong yang ada sangat sempit.

Beberapa studi di Indonesia menunjukkan bahwa pemukiman kumuh memiliki ciri-ciri yang sama seperti: (a) kepadatan yang tinggi, sekitar 600 - 1.000 jiwa per hektar, suplai air yang tidak memadai, sanitasi buruk, drainase buruk, jalan lingkungan yang becek dan sempit, serta tidak memiliki akses terhadap jasa pembuangan sampah, (b) sebagian besar kepala keluarga di pemukiman kumuh tidak berpenghasilan tetap, rata-rata tidak berpendidikan atau tidak tamat SD, gizi balita buruk dan banyak di antara anggota keluarga berpenyakit khronis. ${ }^{6}$

Pemukiman kumuh di Lingkungan Lette, Kecamatan Mariso mempunyai penduduk yang padat dan rata-rata setiap rumah tangga dihuni oleh kurang lebih 7 orang. Pada umumnya tingkat pendidikan orang tua rata-rata tamat SD sehingga untuk mencari nafkah kebanyakan bekerja di sektor informal seperti tukang becak, buruh harian, nelayan, pedagang kaki lima, dan lain-lain dengan penghasilan yang mereka peroleh secara harian dengan kisaran antara $R p$ 10.000,- sampai Rp 20.000,- setiap harinya.

Mereka bekerja untuk menghidupi keluarganya dan menyekolahkan anakanaknya dari jenjang pendidikan mulai dari tingkat SD, SLTP, sampai SMU. Bahkan, ada yang sampai pada perguruan tinggi. Tingkat pendidikan anak pada pemukiman kumuh di Kelurahan Lette diperkirakan 80 persen berpendidikan SLTP ke bawah dan 20 persen berpendidikan SMU ke atas.

Tingkat pendidikan tinggi anak pada pemukiman kumuh di Kelurahan Lette dipengaruhi oleh berbagai faktor, yaitu faktor tingkat pendidikan orang tua, tingkat pendapatan keluarga, jumlah anak, lingkungan, kemampuan atau intelegensi anak dan sebagainya. 
Di antara sekian banyak faktor yang dapat mempengaruhi tingkat pendidikan anak pada pemukiman kumuh, maka peneliti tertarik untuk meneliti faktor tingkat pendidikan orang tua, tingkat pendapatan keluarga, dan jumlah anak yang dianggap sebagai hal yang dominan yang dapat berpengaruh terhadap tingkat pendidikan anak.

Kajian terhadap faktor-faktor pengaruh tingkat pendidikan anak di pemukiman kumuh berikut ini dapat menjadi salah satu upaya untuk memahami masyarakat pemukiman kumuh sebagai suatu entitas.

\section{DETERMINAN VARIABEL PENGARUH TERHADAP TINGKAT PENDIDIKAN ANAK}

Pendidikan adalah suatu proses yang menimbulkan terjadinya suatu perubahan atau pembaruan dalam tingkah laku dan atau kecakapan. Baik atau tidaknya pendidikan itu tergantung kepada bermacam-macam faktor yang mempengaruhinya. Adapun faktor-faktor yang dapat berpengaruh terhadap tingkat pendidikan anak dapat dibedakan menjadi dua bagian: (1) Faktor individual, yaitu semua faktor yang berasal dari dalam diri anak. Misalnya faktor kesehatan, inteligensi, perhatian, bakat, motivasi, dan faktor kepribadian, dan (2) Faktor sosial, yaitu semua faktor yang berada di luar diri anak. Misalnya, faktor tingkat pendidikan orang tua, tingkat pendapatan keluarga, jumlah anak, lingkungan, dan cara belajar. ${ }^{7}$

Berikut ini akan diuraikan faktor-faktor yang dapat berpengaruh terhadap tingkat pendidikan.

\section{Faktor Individual}

Faktor individual meliputi: faktor kesehatan, faktor inteligensi, faktor perhatian, bakat, minat, motivasi, dan faktor kepribadian.

\section{Faktor Sosial}

\section{Tingkat Pendidikan Orang Tua}

Tingkat pendidikan orang tua dianggap faktor yang paling berpengaruh terhadap tingkat pendidikan anak, sebab semakin tinggi tingkat pendidikan orang tua, semakin positif sikapnya terhadap peranan sekolah. Hal ini berarti bahwa tingkat pendidikan orang tua itu berkorelasi dengan sikap positif terhadap pendidikan. Selain itu, tingkat pendidikan orang tua juga berpengaruh terhadap pekerjaan dan berkorelasi dengan tingkat pendapatan. Semakin tinggi tingkat pendidikan seseorang, maka semakin besar pula penghasilan yang akan diperoleh. Mereka yang berpendidikan tinggi dapat terserap pada sektor-sektor modern (formal) yang memiliki penghasilan yang lebih besar dibanding dengan sektor tradisional (informal).

\section{Tingkat Pendapatan Keluarga}

Faktor pendapatan keluarga juga menentukan keberhasilan anak mencapai tingkat pendidikan yang lebih tinggi. Pada keluarga yang ekonominya kurang mung- 
kin dapat menyebabkan anak kekurangan gizi, kebutuhan-kebutuhan anak mungkin tidak dapat terpenuhi. Selain itu, ekonomi yang kurang menyebabkan suasana rumah menjadi muram dan gairah untuk belajar tidak ada. Tetapi, hal ini tidak mutlak demikian. Kadang-kadang kesulitan ekonomi bisa menjadi pendorong anak untuk lebih berhasil, sebaliknya bukan berarti pula ekonomi yang berlebihan tidak akan menyebabkan kesulitan belajar. Pada ekonomi yang berlebihan, anak mungkin akan terlalu dipenuhi semua kebutuhannya sehingga perhatian anak terhadap pelajaran sekolah akan berkurang karena anak terlalu banyak bersenang-senang, misalnya dengan permainan yang beraneka ragam atau pergi ke tempat-tempat hiburan dan lain-lain.

Anak yang berasal dari keluarga yang status ekonominya tinggi menunjukkan prestasi belajar yang lebih tinggi dan dapat bersekolah lebih lama dibandingkan dengan anak yang berasal dari keluarga dengan latar belakang ekonominya yang rendah. Selain itu, apabila tingkat pendapatan orang tua tinggi, memungkinkan dapat membiayai pendidikan anaknya sampai pada tingkat yang lebih tinggi, sehingga dengan demikian, anak akan mampu mencapai pendidikan yang lebih tinggi pula.

\section{Jumlah Anak}

Jumlah anak dapat pula mempengaruhi tingkat pendidikan anak. Jumlah anak yang sedikit di lain pihak dapat berdampak terhadap penyediaan biaya pendidikan bagi anak. Semakin sedikit jumlah anak maka semakin besar peluang bagi anak untuk melanjutkan pendidikan sehingga anak dapat mencapai pendidikan yang lebih tinggi, dibanding jika jumlah anak banyak. Hal ini sejalan dengan pandangan Perwira bahwa anak yang lebih sedikit, beban untuk menanggung berbagai keperluan anak seperti biaya pendidikan, kesehatan, gizi dan sebagainya akan menjadi ringan. ${ }^{8}$

Dari sekian banyak faktor yang dapat berpengaruh terhadap tingkat pendidikan anak, maka penulis hanya mengambil tiga faktor saja, yaitu faktor tingkat pendidikan orang tua, tingkat pendapatan keluarga, dan jumlah anak. Alasannya karena ketiga faktor tersebut merupakan faktor yang paling dominan yang dapat berpengaruh terhadap tingkat pendidikan anak. Selain itu, karena terbatasnya tenaga, biaya, dan waktu.

\section{METODE PENELITIAN}

\section{Lokasi Penelitian}

Penelitian ini dilakukan pada lokasi pemukiman kumuh di Kelurahan Lette, Kecamatan Mariso, Kota Makassar. Kelurahan Lette terletak di pesisir pantai Mariso, sebelah selatan barat daya Kota Makassar. Luas seluruh wilayah kelurahan ini adalah 15 ha. dengan batas-batas: sebelah utara dengan Kelurahan Panambungan, sebelah timur dengan wilayah Kecamatan Ujungpandang, sebelah selatan dengan Kelurahan Mariso, dan sebelah barat dengan selat Makassar. Kawasan pemukiman, khususnya pada pesisir pantai kelurahan ini seluas 7 ha. diidentifikasikan sebagai kawasan kumuh. 
Pemilihan lokasi penelitian tersebut didasarkan atas beberapa pertimbangan, yaitu:

1. Pemukiman tersebut memperlihatkan ciri-ciri pemukiman kumuh, yaitu lingkungan pemukiman di wilayah ini sangat padat dan kondisinya kurang sehat.

2. Dalam wilayah pemukiman tersebut rata-rata keluarga mempunyai anak berpendidikan mulai dari Sekolah Dasar sampai Perguruan Tinggi.

\section{Jenis Penelitian}

Berdasarkan jenis data yang akan diamati, maka penelitian ini termasuk penelitian survei yang mempelajari data dari sampel, sehingga ditemukan kejadian-kejadian relatif, distribusi dan hubungan antar variabel. Hal ini sesuai pendapat Nazir bahwa metode survei adalah penyelidikan yang diadakan untuk memperoleh faktafakta dari gejala-gejala yang ada dan mencari keterangan-keterangan secara faktual, baik tentang institusi sosial, ekonomi atau politik dari suatu kelompok ataupun suatu daerah penyelidikan dilakukan dalam waktu yang bersamaan terhadap sejumlah individu atau unit, baik secara sensus maupun dengan menggunakan sampel. ${ }^{9}$

Penelitian ini adalah survei yang dilakukan pada keluarga yang bermukim di lingkungan kumuh untuk melihat faktor-faktor yang berpengaruh terhadap tingkat pendidikan anak. Penelitian survei dirancang untuk mendapatkan data tentang berbagai gejala yang terjadi pada Kelurahan Lette sebagai lokasi penelitian. Selain itu, juga berbagai kondisi yang terjadi setiap hari pada kehidupan keluarga di kelurahan tersebut.

\section{Definisi Operasional Variabel}

Untuk memberikan pemahaman yang jelas mengenai masalah yang diteliti maka perlu diberikan definisi mengenai variabel-variabel yang akan diteliti:

1. Tingkat pendidikan anak yang dimaksudkan adalah pendidikan formal yaitu mulai dari Sekolah Dasar sampai Perguruan Tinggi.

2. Tingkat pendidikan orang tua yang dimaksudkan adalah pendidikan formal/non formal yang telah didapatkan orang tua, yang tentunya memberikan pengaruh terhadap kesempatan anak bersekolah dengan tingkat pendidikan yang lebih tinggi, dihitung dalam tahun pendidikan.

3. Pendapatan keluarga dimaksudkan adalah jumlah seluruh pendapatan keluarga yang diperoleh kepala keluarga dan anggota keluarga dan penggunaannya untuk seluruh anggota keluarga. Variabel ini diukur dengan jumlah rupiah.

4. Jumlah anak atau tanggungan adalah semua anggota keluarga makan dari satu dapur. Variabel ini diukur dari jumlah orang yang ditanggung dan makan dari satu dapur.

\section{Populasi dan Sampel}

Populasi dari penelitian ini adalah semua keluarga yang mempunyai anak berpendidikan mulai dari Sekolah Dasar sampai Perguruan Tinggi yang berdiam dalam wilayah pemukiman kumuh di Kelurahan Lette, Kecamatan Mariso, Kota Makassar 
yang berjumlah 963 keluarga. Selanjutnya, untuk menentukan besarnya sampel atau responden dalam penelitian ini diambil acuan 15 persen dari besarnya populasi. Jumlah sampel yang diambil adalah 145 keluarga. Adapun teknik pengambilan sampel dilakukan secara acak (random sampling).

\section{Teknik Pengumpulan Data}

Dalam upaya mengumpulkan data yang akurat mengenai variabel-variabel yang akan dipelajari, peneliti menggunakan beberapa teknik, yaitu:

1. Wawancara dan kuesioner, teknik ini dimaksudkan untuk memperoleh data dari responden tentang tingkat pendidikan, tingkat pendapatan, dan jumlah anak atau tanggungan.

2. Dokumentasi, teknik ini dimaksudkan untuk memperoleh data tentang jumlah penduduk yang bermukim di lingkungan kumuh dan jumlah anak-anak yang bersekolah.

3. Observasi, dimaksudkan untuk memperoleh data mengenai kondisi lingkungan pemukiman kumuh di Kota Makassar.

\section{Teknik Analisis Data}

Data yang diperoleh dari hasil penelitian akan diolah dengan menggunakan analisis deskriptif dan analisis statistik inferensial. Analisis statistik deskriptif dilakukan dengan mendeskripsikan semua data dari semua variabel dalam bentuk distribusi frekuensi.

Untuk menguji pengaruh antara variabel bebas seperti tingkat pendidikan orang tua, tingkat pendapatan keluarga, dan jumlah anak terhadap tingkat pendidikan anak yang mempunyai data kuantitatif dipakai uji statistik regresi ganda. ${ }^{10}$

\section{HASIL PENELITIAN DAN PEMBAHASAN}

\section{Hasil Penelitian}

\section{Tingkat Pendidikan Orang Tua}

Kualitas manusia banyak ditentukan oleh tingkat pendidikan manusia itu sendiri. Untuk itu aspek pendidikan merupakan faktor yang sangat penting dalam berbagai aktivitas manusia dalam kehidupannya. Termasuk aktivitas manusia dalam menerima ataupun menolak suatu inovasi baru.

Data tingkat pendidikan orang tua yang diperoleh menunjukkan bahwa proporsi terbanyak dari orang tua yang berdiam di pemukiman kumuh adalah mereka yang mempunyai tingkat pendidikan Sekolah Dasar (1-6 tahun) sebanyak 59,31 persen, kemudian disusul dengan SLTP (7-9 tahun) sebanyak 22,07 persen, SMU (1012 tahun) sebanyak 15,86 persen, dan tingkat pendidikan Perguruan Tinggi (16 tahun-18 tahun) sebanyak 2,76 persen.

Nilai rata-rata tingkat pendidikan orang tua adalah 7,041. Dengan demikian, dapat disimpulkan bahwa tingkat pendidikan orang tua umumnya tergolong rendah. Hal ini didasarkan pada kategori sebagai berikut: 


\begin{tabular}{|c|c|c|c|c|}
\hline SD (1-6 tahun) & $=$ & 59,31 persen & $=$ & Rendah \\
\hline - SLTP-SMU (7-12 tahun) & & 37,93 persen & $=$ & Sedang \\
\hline - PT (13-18 tahun) & $=$ & 2,76 persen & $=$ & Tinggi \\
\hline
\end{tabular}

\section{Tingkat Pendapatan Keluarga}

Besarnya pendapatan mempunyai kaitan yang erat dengan jenis pekerjaan seseorang. Pada umumnya responden bekerja pada sektor informal seperti tukang becak, tukang batu, nelayan, pedagang kaki lima, dan sebagainya sehingga untuk menentukan besarnya pendapatan mereka tidaklah mudah. Hal ini disebabkan karena kegiatan informal di samping waktunya tidak tetap, juga besarnya pendapatan tidaklah menentu. Pendapatan mereka umumnya banyak ditentukan oleh modal kerja, volume usaha, dan menurut mereka yang paling menentukan adalah "rejeki" mereka pada hari itu.

Dalam menghitung besarnya pendapatan mereka, yang dilakukan pertama-tama adalah ukuran pendapatan harian, sebab bagaimanapun juga para pekerja informal melakukan aktivitas usahanya setiap hari, dan pendapatan hanya mungkin dapat diperoleh apabila melakukan aktivitas usahanya pada hari tersebut. Para pekerja yang menjadi tukang bagi mereka yang melakukan pekerjaan borongan dihitung dengan melihat berapa besar kegiatan borongan yang dikerjakan dan dalam berapa hari bisa diselesaikan. Untuk keperluan analisis data nantinya, maka besar pendapatan diukur dengan menggunakan ukuran bulanan. Tentunya dalam penentuan besarnya pendapatan ini diperhitungkan juga kemungkinan tidak bekerja dalam beberapa hari pada bulan yang bersangkutan.

Untuk keperluan analisis data, maka dalam penyajian data diadakan pengelompokan pada besarnya pendapatan. Data yang diperoleh menunjukkan bahwa proporsi tertinggi dari responden mempunyai penghasilan kurang dari Rp 500.000,- setiap bulan yaitu sebanyak 64,14 persen, kemudian disusul oleh mereka yang berpenghasilan Rp 500.000,- hingga Rp 1.000.000,- sebanyak 33,79 persen, dan proporsi yang paling sedikit adalah mereka yang berpenghasilan lebih dari Rp 1.000.000,- sebanyak 2,07 persen.

Nilai rata-rata tingkat pendapatan keluarga adalah 449.137,931. Dengan demikian, dapat disimpulkan bahwa pada umumnya responden mempunyai pendapatan yang rendah.

Penelitian yang dilakukan oleh Mangunrai pada pekerja sektor informal menemukan bahwa rata-rata penghasilan pekerja sektor informal untuk setiap bulannya adalah Rp 96.740,- dengan proporsi terbanyak adalah penghasilan di atas Rp 100.000,setiap bulannya. ${ }^{11}$ Dari penelitian Mangunrai memperlihatkan bahwa dalam kurun waktu tujuh tahun terakhir ini telah terjadi kenaikan besar pendapatan, tetapi bila dilihat dari inflasi setiap tahunnya, penghasilan responden yang berdiam pada pemukiman kumuh tidak banyak atau malah mungkin tidak ada sama sekali kenaikan ataupun perbaikan pendapatan. 


\section{Jumlah Anak}

Jumlah anak yang dimaksudkan dalam penelitian ini adalah anak yang harus dibiayai atau ditanggung. Data yang diperoleh menunjukkan bahwa ternyata responden yang berdiam pada wilayah pemukiman kumuh di Kelurahan Lette paling banyak mempunyai 1-2 orang anak yaitu sebesar 68,96 persen, disusul dengan responden yang mempunyai anak 3-4 orang sebanyak 26,21 persen, dan responden yang mempunyai anak 5-6 orang sebanyak 4,83 persen.

Nilai rata-rata jumlah anak adalah 2,207. Dapat disimpulkan bahwa rata-rata keluarga mempunyai jumlah anak termasuk dalam kategori rendah.

\section{Tingkat Pendidikan Anak}

Tingkat pendidikan anak yang dimaksudkan dalam penelitian ini adalah pendidikan formal yaitu mulai Sekolah Dasar (SD) sampai Perguruan Tinggi (PT). Data yang diperoleh menunjukkan bahwa proporsi terbanyak dari responden yang berdiam di pemukiman kumuh adalah mereka yang mempunyai anak berpendidikan SLTP (7-9 tahun) sebanyak 41,38 persen, kemudian disusul dengan yang berpendidikan SD (1-6 tahun) sebanyak 33,10 persen, berpendidikan SMU (10-12 tahun) sebanyak 20,69 persen, dan Perguruan Tinggi (13-18 tahun) sebanyak 4,83 persen.

Nilai rata-rata tingkat pendidikan anak adalah 8,179. Dengan demikian, dapat disimpulkan bahwa tingkat pendidikan anak umumnya tergolong sedang. Hal ini didasarkan pada kategori sebagai berikut:

$\begin{array}{lllll}-\mathrm{SD}(1-6 \text { tahun}) & = & 33,10 \text { persen } & = & \text { Rendah } \\ -\mathrm{SLTP}-\mathrm{SMU}(7-12 \text { tahun }) & = & 62,07 \text { persen } & = & \text { Sedang } \\ -\mathrm{PT}(13-18 \text { tahun) } & = & 4,83 \text { persen } & = & \text { Tinggi }\end{array}$

\section{Pengaruh Tingkat Pendidikan Orang Tua, Tingkat Pendapatan Keluarga dan Jumlah Anak terhadap Tingkat Pendidikan Anak}

Berdasarkan hasil analisis regresi linear ganda antara pasangan data tingkat pendidikan orang tua (variabel $X_{1}$ ), tingkat pendapatan keluarga (variabel $X_{2}$ ) dan jumlah anak (variabel $\mathrm{X}_{3}$ ) dengan tingkat pendidikan anak (variabel $\mathrm{Y}$ ), diketahui bahwa nilai koefisien regresi ganda $b_{1}=0,545, b_{2}=0,379$ dan $b_{3}=-0,854$ dengan nilai konstanta a sebesar 4,521.

Hasil analisis uji "F" diperoleh nilai sebesar 22,344 > nilai $\mathrm{F}_{\text {tabel }}(0,01)$ sebesar 3,94. Ini menunjukkan bahwa koefisien korelasi antara tingkat pendidikan orang tua, tingkat pendapatan keluarga, dan jumlah anak secara bersama-sama mempunyai pengaruh yang signifikan terhadap tingkat pendidikan anak. Dengan demikian, hipotesis yang menyatakan tingkat pendidikan orang tua, tingkat pendapatan keluarga, dan jumlah anak secara bersama-sama berpengaruh terhadap tingkat pendidikan anak diterima dan hasil ujinya dapat dinyatakan signifikan.

Untuk mengetahui besarnya sumbangan efektif tingkat pendidikan orang tua, tingkat pendapatan keluarga dan jumlah anak terhadap tingkat pendidikan anak dapat dilihat dari koefisien determinasinya $\left(\mathrm{R}^{2}\right)$ sebesar 0,32 . 
Dengan demikian, dapat disimpulkan bahwa besarnya sumbangan efektif tingkat pendidikan orang tua, tingkat pendapatan keluarga, dan jumlah anak terhadap tingkat pendidikan anak adalah 32 persen, dalam arti bahwa 68 persen lainnya dipengaruhi oleh variabel lain yang tidak diamati dalam penelitian ini.

\section{PEMBAHASAN}

Tingkat pendidikan orang tua berpengaruh terhadap tingkat pendidikan anak. Semakin tinggi tingkat pendidikan orang tua maka semakin tinggi pula tingkat pendidikan anaknya. Hal ini didasarkan pada data yang diperoleh bahwa sebanyak 15,86 persen orang tua di pemukiman kumuh Kelurahan Lette berpendidikan SMU dan 2,76 persen berpendidikan tinggi (PT). Tingginya tingkat pendidikan orang tua dapat berpengaruh terhadap tingkat pendidikan anak-anaknya. Ini dapat dilihat pada data yang diperoleh yaitu sebanyak 20,69 persen anak-anak di pemukiman kumuh Kelurahan Lette berpendidikan SMU, 1,38 persen berpendidikan Diploma dan 3,45 persen berpendidikan tinggi (PT).

Hal ini didukung oleh pendapat Mahmud bahwa dalam menentukan masa depan anak, faktor sosial ekonomi keluarga sangat menentukan. Status sosial ekonomi keluarga antara lain meliputi tingkat pendidikan, pekerjaan, dan penghasilan orang tua. Di antara sub-faktor tersebut, yang paling berpengaruh terhadap kelangsungan pendidikan anak di sekolah adalah tingkat pendidikan orang tua. Sebab semakin tinggi tingkat pendidikan orang tua itu, semakin positif sikapnya terhadap peranan sekolah. Hal ini berarti bahwa tingkat pendidikan orang tua itu berkorelasi dengan sikap positif terhadap pendidikan.

Tingkat pendapatan keluarga sangat terkait dengan peningkatan pendidikan anak. Hal ini didukung oleh hasil penelitian Alwin dan Thornton dalam Mahmud bahwa murid-murid yang berasal dari keluarga yang berstatus sosial ekonomi tinggi menunjukkan prestasi belajar lebih tinggi dan dapat bersekolah lebih lama ketimbang murid-murid yang berasal dari keluarga dengan latar belakang sosial ekonomi yang rendah.

Pada hakikatnya pendapatan keluarga merupakan perolehan hasil dari kegiatan ekonomi keluarga. Ekonomi keluarga mempunyai peranan terhadap pembentukan anak. Misalnya keluarga yang perekonomiannya cukup, menyebabkan lingkungan materialnya yang dihadapi anak di dalam keluarganya akan lebih luas, sehingga ia mendapat kesempatan yang lebih banyak dalam mengembangkan bermacam-macam kecakapan. Hubungan sosial antara anak-anak dengan orang tuanya ternyata berlainan juga dalam bentuk-bentuknya, misalnya keluarga yang ekonominya cukup, hubungan antara orang tua dan anak-anaknya akan lebih baik sebab orang tua tidak tertekan di dalam mencapai kebutuhan-kebutuhan hidupnya sehingga perhatiannya dapat dicurahkan kepada anak-anaknya. Jadi orang tua dalam hal ini mencurahkan perhatian yang lebih mendalam kepada pendidikan anaknya karena tidak disulitkan dengan perkara kebutuhan primer kehidupan manusia. 
Hal tersebut di atas sejalan dengan apa yang diungkapkan oleh Abu Ahmadi, bahwa keadaan ekonomi keluarga dapat juga berperan terhadap perkembangan anak-anak. Misalnya anak-anak yang orang tuanya berpenghasilan cukup, maka anak-anak tersebut lebih banyak mendapatkan kesempatan untuk memperkembangkan bermacam-macam kecakapan begitu pula sebaliknya.

Dalam hal kemampuan intelegensi pun nampak adanya perbedaan sebagai akibat dari status sosial ekonomi keluarga. Menurut Kemmeyer bahwa ada hubungan dengan kemampuan intelegensi rata-rata. Hal ini terlihat di Polandia, pada masyarakat petani tradisional yaitu masyarakat yang memiliki status sosial ekonomi yang baik cenderung memiliki anak-anak yang berintelegensi tinggi, dan masyarakat yang berstatus sosial ekonomi yang kurang baik, memiliki anak yang berintelegensi rendah. Hal ini tentu berkaitan dengan faktor penyediaan gizi yang cukup serta fasilitas belajar yang memadai.

Menurut Slameto, keadaan ekonomi keluarga erat hubungannya dengan belajar anak. Anak yang sedang belajar selain harus terpenuhi kebutuhan pokoknya, misalnya makan, minum, pakaian, perlindungan kesehatan dan lain-lainnya juga membutuhkan fasilitas belajar seperti ruang belajar, meja, kursi, penerangan, alat tulis menulis, buku-buku dan lain-lain. Fasilitas belajar itu hanya dapat dipenuhi jika keluarga mempunyai cukup uang.

Jika anak hidup dalam keluarga yang miskin, kebutuhan pokok anak kurang terpenuhi, akibat kesehatan anak terganggu sehingga belajar anak juga terganggu. Akibat yang lain anak selalu dirundung kesedihan sehingga anak merasa minder dengan teman lain, hal ini pasti mengganggu belajar anak. Bahkan mungkin anak harus bekerja mencari nafkah sebagai pembantu orang tuanya walaupun sebenarnya anak belum saatnya untuk bekerja, hal yang begitu juga akan mengganggu belajar anak.

Jaelani mengatakan bahwa orang yang mempunyai kedudukan ekonomi yang lebih baik, cenderung mempunyai jumlah anak yang berintelegensi tinggi dibanding dengan anak miskin, tetapi tidak menjamin bahwa prestasi belajar mereka juga harus lebih tinggi. Diperkirakan bahwa sosial ekonomi keluarga yang baik dapat mempengaruhi pemberian gizi yang baik dan seterusnya akan dapat meningkatkan kesehatan dan intelegensi anak. Pengaruh lanjut dari gizi yang baik adalah pembuatan sel-sel tubuh dan saraf yang normal yang sangat menentukan tingkat kecerdasan seseorang.

Menurut Jaelani bahwa kemampuan dan prestasi belajar anak tidak hanya ditentukan oleh kemampuan internal saja, tetapi juga oleh pengaruh faktor-faktor eksternal. Faktor eksternal itu antara lain lingkungan termasuk lingkungan sosial ekonomi anak, yang turut menunjang dan menentukan keberhasilan pendidikan. Sering orang berkata bahwa pendidikan tidak dapat berjalan secara baik tanpa didukung sosial ekonomi yang baik. Oleh karena, itu faktor-faktor sosial ekonomi keluarga banyak mempengaruhi tingkat pendidikan anak.

Sejalan dengan pernyataan tersebut di atas bahwa anak bisa melanjutkan pendidikannya, mulai dari yang terendah sampai ke jenjang yang lebih tinggi, sangat dipe- 
ngaruhi oleh tingkat pendapatan orang tua. Akan tetapi, apabila hal itu tidak terpenuhi, anak yang mempunyai keinginan untuk melanjutkan pendidikan sering kali tidak dapat terwujud, karena hambatan pertama masalah ekonomi. Kondisi yang demikian jelaslah bahwa kemiskinan orang tua, baik ilmu pengetahuan maupun kekayaan akan mempengaruhi pendidikan anak mereka.

Uraian di atas, semakin jelas bahwa faktor pendapatan keluarga merupakan faktor penentu dalam meningkatkan pendidikan anak. Tanpa ekonomi yang cukup pendidikan anak akan sulit terwujud menjadi kenyataan. Dalam kaitannya dengan peningkatan pendidikan anak, hal ini sangat terkait juga dengan besarnya keluarga (jumlah anak). Sidi berpendapat bahwa semakin besar jumlah anggota keluarga (jumlah anak), semakin rendah jumlah rata-rata kalori dan protein yang dapat dikonsumsi oleh setiap anggota keluarga, terutama pada keluarga yang berpenghasilan rendah.

Hal ini sejalan dengan yang dikatakan Perwira bahwa jumlah anak yang lebih sedikit membuat orang tua lebih ringan dalam menanggung berbagai keperluan anak seperti biaya pendidikan, kesehatan, gizi dan sebagainya. Hasil penelitian Tauran dalam Ahmadi mengungkapkan bahwa pada umumnya keluarga yang mempunyai banyak anak terdapat dalam tingkat sosial ekonomi yang rendah. Orang tua yang berasal dari tingkat sosial ekonominya yang tinggi dan menengah cenderung membatasi anak-anak mereka dan jumlahnya relatif kecil sehingga sanggup membiayai pendidikannya sampai tingkat perguruan tinggi.

Orang tua yang berpendidikan kebanyakan membatasi anak-anak mereka dengan jumlah yang relatif kecil. Pertimbangannya berdasarkan pada kemungkinan pembinaan anak dalam pendidikan dan perhitungan ekonomis, sedangkan yang berpendidikan rendah dan berwawasan sempit lebih berpedoman pada banyak anak banyak rejeki.

Mengacu pada pendapat tersebut dapat dikatakan bahwa semakin banyak anggota keluarga (jumlah anak) dalam suatu keluarga akan semakin banyak biaya yang harus disiapkan untuk digunakan dalam memenuhi kebutuhan sehari-hari termasuk di dalamnya biaya pendidikan dan fasilitas belajar lainnya.

Selain tingkat pendidikan orang tua, tingkat pendapatan keluarga dan jumlah anak yang dapat berpengaruh terhadap tingkat pendidikan anak, jenis pekerjaan orang tua, jumlah anggota keluarga dan kondisi lingkungan tempat tinggal anak dapat pula berpengaruh terhadap tingkat pendidikan anak.

Jenis pekerjaan orang tua dapat pula berpengaruh terhadap tingkat pendidikan anak karena berkaitan dengan tingkat pendapatan. Mereka yang bekerja pada sektorsektor modern (formal) memiliki penghasilan yang lebih besar dibanding dengan mereka yang bekerja di sektor tradisional (informal).

Pada umumnya penduduk atau keluarga yang tinggal di pemukiman kumuh Kelurahan Lette mempunyai pekerjaan yang tidak tetap seperti tukang becak, buruh harian, nelayan, jualan dan sebagainya dengan penghasilan yang mereka peroleh sangat rendah sehingga sulit menjamin pemenuhan kebutuhan sehari-hari termasuk di 
dalamnya biaya pendidikan dan fasilitas belajar lainnya. Hal ini dapat dimaklumi, sebab wilayah pemukiman kumuh umumnya dihuni oleh mereka yang mempunyai pekerjaan pada sektor informal perkotaan.

Sejalan dengan itu, hasil penelitian Masykur mengemukakan beberapa sifat yang menonjol dari pemukiman kumuh, antara lain kebanyakan penghuni pemukiman kumuh adalah mereka yang berpenghasilan rendah, biasanya terdiri atas buruh-buruh bangunan, penjual bakso, tukang becak, pembantu rumah tangga dan lain-lain. Mereka itu berpenghasilan secara harian dengan kisaran antara Rp 2.000,sampai dengan Rp 6.000,- setiap harinya. Dari uraian tersebut, dapat disimpulkan bahwa jenis pekerjaan sangat berpengaruh terhadap tingkat pendidikan anak karena berkaitan dengan tingkat pendapatan.

Besarnya anggota keluarga dapat pula berpengaruh terhadap tingkat pendidikan anak. Hal ini disebabkan karena semakin banyaknya anggota keluarga dalam suatu keluarga akan semakin banyak pula biaya yang harus disiapkan untuk memenuhi kebutuhan hidup mereka termasuk biaya pendidikan anak-anaknya. Hasil penelitian menunjukkan bahwa rata-rata keluarga di pemukiman kumuh Kelurahan Lette mempunyai anggota keluarga antara 5 hingga 7 orang. Keadaan tersebut menunjukkan bahwa umumnya kepala keluarga mempunyai tanggungan yang tergolong besar. Hal ini dapat dimaklumi sebab masyarakat miskin biasanya ditandai dengan adanya jumlah anggota keluarga yang tergolong banyak.

Besarnya anggota rumah tangga akan mempengaruhi tingkat konsumsi dan pemenuhan kebutuhan hidup mereka. Bila dibandingkan dengan tingkat pendapatan rumah tangga dengan besarnya anggota rumah tangga yang menjadi tanggungannya, dapat dimaklumi bila mereka akan senantiasa terbelit dengan kehidupan yang serba kekurangan, sehingga terjadilah kemiskinan yang berlangsung secara terus menerus bagi kehidupan mereka.

Dari uraian di atas, maka dapat disimpulkan bahwa faktor penyebab rendahnya tingkat pendidikan anak di pemukiman kumuh Kelurahan Lette adalah: (1) tingkat pendidikan orang tua umumnya rendah sehingga mareka mempunyai sikap yang negatif terhadap pendidikan anak-anaknya, (2) rendahnya tingkat pendapatan keluarga disebabkan karena pada umumnya mereka mempunyai pekerjaan sebagai tukang becak dan tukang batu dengan penghasilan yang mereka peroleh sangat rendah sehingga tidak dapat membiayai pendidikan anak-anaknya ke jenjang pendidikan yang lebih tinggi, (3) anak-anak turut bekerja membantu orang tuanya dalam mencari nafkah sehingga tidak lagi melanjutkan pendidikannya, dan (4) rata-rata keluarga mempunyai anak berumur $5-15$ tahun atau berpendidikan SD sampai SLTP.

\section{SIMPULAN}

Tingkat pendidikan orang tua, tingkat pendapatan keluarga dan jumlah anak masih tergolong rendah, sehingga dapat berpengaruh terhadap tingkat pendidikan anak. Kondisi ini menunjukkan bahwa tingkat pendidikan orang tua, tingkat pendapatan keluarga, dan jumlah anak merupakan tiga variabel yang penting untuk diperhatikan dalam peningkatan pendidikan anak. 


\section{SARAN}

Berdasarkan kesimpulan penelitian yang telah dikemukakan di atas, maka diajukan beberapa saran, yaitu:

1. Dalam upaya meningkatkan harkat dan martabat manusia, maka masyarakat yang berdiam pada wilayah pemukiman kumuh perlu mendapat perhatian dalam masalah pendidikan, ekonomi, kesehatan lingkungan, dan sebagainya. Hal itu, dikarenakan di samping mereka merupakan jumlah yang besar yang mendiami tempat di dalam wilayah perkotaan, mereka juga hidup dalam serba kekurangan sehingga gizi dan kesehatan lingkungan yang buruk dapat menyebabkan timbulnya masalah yang dapat mempengaruhi pendidikan pada anak-anak sebagai generasi muda yang akan datang.

2. Perlu perhatian yang serius baik dari pemerintah Kota Makassar maupun instansi yang terkait untuk senantiasa memberikan pinjaman modal usaha dibarengi dengan bekal keterampilan kerja yang dapat memotivasi dirinya untuk merubah pola hidupnya yang lebih baik serta memberikan beasiswa kepada anak-anak yang sementara dalam melanjutkan pendidikannya.

\section{CATATAN AKHIR}

1. Undang-Undang R.I. Nomor 20 Tahun 2003, Sistem Pendidikan Nasional, Jogjakarta: Laksana, 2012, h. 15.

2. Ibid., h. 19.

3. M. Idrus Abustam, "Peranan Keluarga dalam Meningkatkan Kualitas Sekolah", Makalah pada Seminar Sehari dalam Rangka Memperingati Hari Guru Nasional tahun 1996 Sulawesi Selatan pada hari Senin, tanggal 2 Desember 1996, 1996, h. 14.

4. Y. Sutopo, Produktivitas dan Tenaga Kerja Indonesia, Seri II, Jakarta: Lembaga Sarana Informasi Usaha dan Produktivitas, 1985, h. 106.

5. Makkulau, Zona-zona Transisi dalam Kotamadya Dati II Ujungpandang, Ujungpandang: IKIP, 1987, h. 87.

6. Muhammad Ardi, Kualitas Lingkungan Hidup Indonesia, Jakarta: Kantor Menteri Negara Kependudukan dan Lingkungan Hidup, 1992, h. 64.

7. M. Ngalim Purwanto, Psikologi Pendidikan, Bandung: Remadja Karya, 1985, h. 102.

8. S.M. Perwira, Gerakan KB dan Kualitas Penduduk (Artikel): Warta Demografi. tahun XXII/ No. 8, Agustus 1992, 1992, h. 39.

9. Moh. Nazir, Metode Penelitian, Jakarta: Ghalia Indonesia, 1999, h. 124.

10. Sujana, Metoda Statistika, Bandung: Tarsito, 1984, h. 347.

11. Hasan Mangunrai, Karakteristik Demografi dan Sosial Ekonomi Pekerja Sektor Informal di Kodya Ujungpandang, Ujungpandang: Hasil Penelitian UNHAS, 1987, h. 58.

\section{DAFTAR PUSTAKA}

Abustam, M. Idrus, "Peranan Keluarga dalam Meningkatkan Kualitas Sekolah". Makalah pada Seminar Sehari dalam Rangka Memperingati Hari Guru Nasional tahun 1996 Sulawesi Selatan pada hari Senin, tanggal 2 Desember 1996, 1996.

Ahmadi, Abu. Sosiologi Pendidika. Jakarta: Rineka Cipta, 1991. 
Ardi, Muhammad. Kualitas Lingkungan Hidup Indonesia. Jakarta: Kantor Menteri Negara Kependudukan dan Lingkungan Hidup, 1992.

Cangara, Syaifullah. „Faktor-faktor yang Berhubungan dengan Tumbuhnya Pemukiman Kumuh di Kalangan Migran Pekerja Sektor Informal Perkotaan di Makassar". Thesis. Makassar: Pascasarjana Unhas, 1995.

Kartono, Kartini. Bimbingan Belajar di SMA dan Perguruan Tinggi. Jakarta: PT. Raja Grafindo Persada, 1995.

Lihawa, Thamrin. Kondisi Sosial Ekonomi Masyarakat Pemukiman Kumuh Kelurahan Cambaya Kecamatan Ujung Tanah Kodya Ujungpandang. Ujungpandang: Hasil Penelitian UNHAS, 1973.

Makkulau. Zona-zona Transisi dalam Kotamadya Dati II Ujungpandang. Ujungpandang: IKIP, 1987.

Mangunrai, Hasan. Karakteristik Demografi dan Sosial Ekonomi Pekerja Sektor Informal di Kodya Ujungpandang. Ujungpandang: Hasil Penelitian UNHAS, 1987.

Masykur. "Perencanaan Lingkungan Partisipasi Swasta dalam Penataan Pemukiman Kumuh". Jurnal. Univ. Borobudur No. 3, 1993.

Moh. Nazir. Metode Penelitian. Jakarta: Ghalia Indonesia, 1999.

Pandu, Maria. Potensi Wanita pada Kelurahan Miskin di Daerah Tingkat II Kodya Ujungpandang Prop. Sulawesi Selatan. Ujungpandang: Hasil Penelitian, 1993.

Perwira, S.M. Gerakan KB dan Kualitas Penduduk (Artikel):: Warta Demografi. tahun XXII/ No. 8, Agustus 1992, 1992.

Purwanto. M. Ngalim. Psikologi Pendidikan. Bandung: Remadja Karya, 1985.

Sidi, I.P. "Perkembangan Anak dan Pengaruh Bentuk Keluarga terhadap Usaha Realisasi Kemampuan Anak". Buku Keluarga Indonesia Menyambut Tahun 2000. BKKBN, 1984.

Singarimbun, M. Kependudukan: Liku-liku Penurunan Kelahiran. Yogyakarta: LP3ES UGM, 1982.

Slameto. Belajar dan Faktor-faktor yang Mempengaruhinya. Jakarta: Direka Cipta, 1995.

Sujana. Metoda Statistika. Bandung: Tarsito, 1984.

Sumardi, Mulyanto. Kemiskinan dan Kebutuhan Pokok. Jakarta: Rajawali Press, 1982.

Sutopo, Y. Produktivitas dan Tenaga Kerja Indonesia. Seri II, Jakarta: Lembaga Sarana Informasi Usaha dan Produktivitas, 1985.

Undang-Undang R.I. Nomor 20 Tahun 2003. Sistem Pendidikan Nasional. Jogjakarta: Laksana, 2012.

Yusuf, Munir. A. Pengantar Ilmu Pendidikan. Jakarta: Ghalia Indonesia, 1986. 